\title{
Polymyositis in childhood as clinical manifestation associated with HTLV-1
}

\author{
Ayrton Silva Ferreira', Carlos Maurício de Castro Costa², \\ Irna Kaden de Sousa Dantas ${ }^{3}$, Terezinha de Jesus Teixeira Santos ${ }^{4}$, \\ Samuel Bovy de Castro Costa ${ }^{5}$, Carlos Campos Câmara ${ }^{6}$, \\ Reinaldo Barreto Oriá7, Francisco de Assis Aquino Gondim
}

The HTLV-1 (human T-cell lymphotropic virus type 1 ) is a retrovirus etiologically associated with tropical spastic paraparesis/HTLV-1 associated myelopathy (TSP/ HAM) and adult T-cell lymphoma/leukemia (ATLL). These two forms of clinical presentation are the best known and studied, although the virus may be also related with other clinical conditions, among them, the polymyositis. In Jamaica and Japan, the association between HTLV-1 seropositivity and polymyositis has been described in $85 \%$ and $16 \%$, respectively ${ }^{1}$.

In the present study, we report a case of polymyositis associated with HTLV-1 as an uncommon form of clinical manifestation in a 10 years-old child mimicking muscular dystrophy.

The possibility of vertical transmission (breast feeding) is outlined in this case. The parents of the patient signed a consent form.

\section{CASE}

KSS, 10 years-old, Caucasian female, coming from Canindé-CE, was admitted in the Service of Neurology of the University Hospital Walter Cantidio of the Federal University of the Ceará, for diagnostic evaluation. Daughter of non-consanguineous parents, evolved with adequate neuropsychomotor development, acquiring independent walk with 1 year and 3 months of age. When she was 5 years-old, she presented muscular weakness, initially in the lower limbs, progressing to the upper limbs, with change of the walk pattern, and significant worsening after the age of 7 years, but without bladder dysfunction.

The neurological examination evidenced muscular weakness, mainly pelvic and scapular, normal muscular tonus, preserved osteotendineous reflexes in the upper limbs, but with bilateral Achilles hyperreflexia. She walks without aid and her locomotion speed corresponds to $50 \%$ of the expected for her age. She showed incapacity of standing up from the ground, even with the aid of a support, and she uses wheelchair for community locomotion.

The laboratorial findings showed elevated muscular enzymes: total creatine kinase of 5,910 UI/L (up to $225 \mathrm{UI} / \mathrm{L}$ ), aldolase of $28.9 \mathrm{U} / \mathrm{L}$ (up to $8.8 \mathrm{U} / \mathrm{L}$ ), lactic dehydrogenase of $373 \mathrm{U} / \mathrm{L}$ (up to 100 to 190 U/L). Positive serology for HTLV-1 (ELISA and Western blot). Non-reagent research for antinuclear factor and rheumatoid-latex factor of $8.5 \mathrm{UI} / \mathrm{mL}$ (up to $20 \mathrm{UI} / \mathrm{mL}$ ). General and specific cerebrospinal fluid study without changes (toxoplasmosis research, schistosomiasis, Mycobacterium tuberculosis, varicela-zoster, cytomegalovirus, electrophoresis of proteins, Epstein-Barr, HIV and HTLV-1/2, herpesvirus-1/2, VDRL).

Electroneuromyography had myopathic pattern (Fig 1), and the somatosensory evoked potential was normal. The magnetic nuclear resonance evidenced diffuse

\section{Correspondence}

Carlos Maurício de Castro Costa Rua Cel. Nunes de Melo 1315 60430-270 Fortaleza CE - Brasil E-mail: mcastro@ufc.br

Received 25 June 2009 Received in final form 11 January 2010 Accepted 18 January 2010

\section{POLIMIOSITE NA INFÂNCIA COMO MANIFESTAÇÃO CLÍNICA ASSOCIADA AO HTLV-1}

Laboratory of Experimental Neurology and Neurophysiology/DFF/UFC and Institute of Biomedicine of the Brazilian Semiarid/ INCT/CNPq: 'MD, MSc; ${ }^{1} \mathrm{MD}$, PhD, Full Professor of Neurology and Neurophysiology/DFF/UFC; ${ }^{3} \mathrm{MD}$, Medical Doctor of the Brasília Base Hospital; ${ }^{4} \mathrm{MSc}, \mathrm{PhD}$, Associate Professor of the Medicine Course of the Christus Faculty; ${ }^{5} \mathrm{DVM}$; ${ }^{6} \mathrm{DVM}, \mathrm{PhD}$, Professor of the Superior School of Agriculture of Mossoró; ${ }^{7} \mathrm{DVM}$, PhD, Associate Professor of Histology/DM/UFC; ${ }^{8} \mathrm{MD}$, $\mathrm{PhD}$, Associate Professor of Neuropsychology/DFF/UFC 
muscular atrophy, suggestive of muscular inflammatory process (Fig 2A and 2D).

Biopsy of the left brachial biceps muscle showed findings compatible with inflammatory myopathy of the polymyositis type.

The immunohistochemistry with marker for T-lymphocyte was positive. Part of the material was fixed in glutaraldeyde and sent for electronic microscopy. The results showed ultrastructural changes compatible with inflammatory myopathy, without, however, evidence of viral particles in the examined material. It was also performed immunohistochemistry with the following markers: merosin, spectrin, dystrophin, myotilin, dyspherlin (HAM- 1 and HAM-3), sarcoglicans $\alpha, \beta, \delta$ and $\gamma$ and dystroglican $\beta$, which did not show specific deficiencies.

\section{DISCUSSION}

The forms of clinical presentation of the HTLV-1 infection may be varied, but TSP/HAM and ATLL are the most common forms ${ }^{2,3}$. Although many aspects of the events that lead to development of diseases associated with HTLV-1 is not established, the variation in immune response is probably responsible for the diversity of clinical manifestations in infection by this retrovirus.

Only around 5\% of the HTLV-1 carriers will become symptomatic years or even decades after the infection.

Polymyositis associated with HTLV-1 has a low incidence, and mainly in childhood, with just a few cases described in the medical literature ${ }^{4}$. This condition may also be associated with uveitis ${ }^{5}$. Inclusion-body myositis has also been described in patients infected with HIV and HTLV $-1^{6}$, and some cases are associated with TSP/HAM and polymyositis with respiratory failure ${ }^{7}$. There is also report of this condition not associated with TSP/HAM ${ }^{8}$.

Diffuse muscular atrophy was detected in the MNR, with signals of effective inflammatory activity (Fig 2) giving support to the diagnosis of polymyositis?.

In the study of this association (HTLV-1 and polymyositis), without spinal cord manifestation, but with immune inflammatory muscular involvement mediated by the virus, there is a predominance of CD8 lymphocytes, macrophages and CD4 lymphocytes ${ }^{10}$.

The epidemiological data of the child and her parent's seropositivity indicated a possible association of the disease with the vertical (breast feeding) infection.

Studies showed that there is no specific and efficient treatment for this infection. Therapy with immunossuppressants and immunomodulators, specially corticosteroids, are used as support for the stabilization of the clinical picture ${ }^{11,12}$.

Despite reports in the medical literature of similar cases of the association of polymyositis with HTLV-1, the alleged relation of cause and effect has not yet been

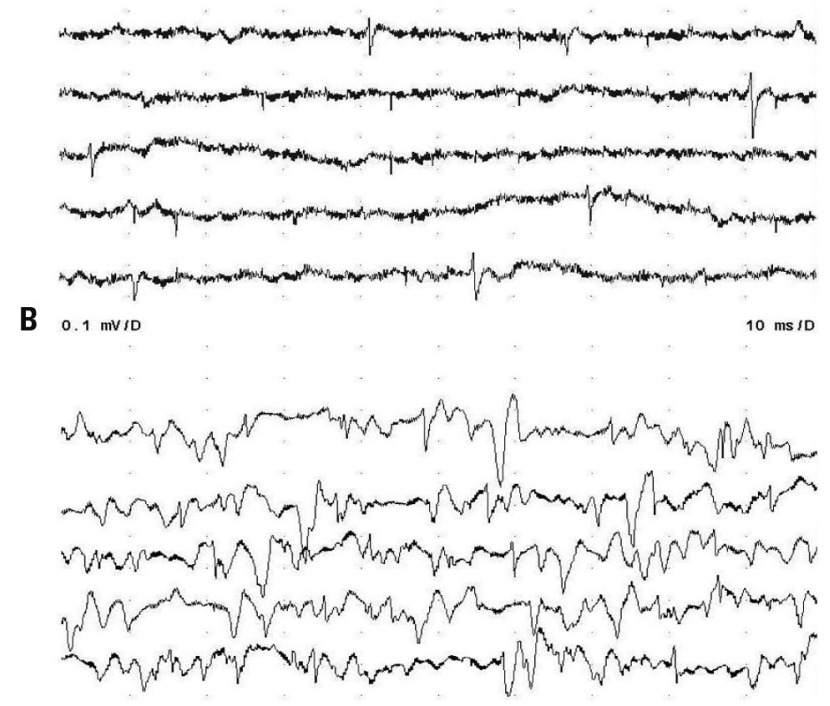

Fig 1. Needle electromyography of the right brachial biceps muscle. [A] Fibrillation potentials and positive waves during the muscular rest; [B] Motor unit potentials with diminished duration and amplitude and paradoxical recruiting.

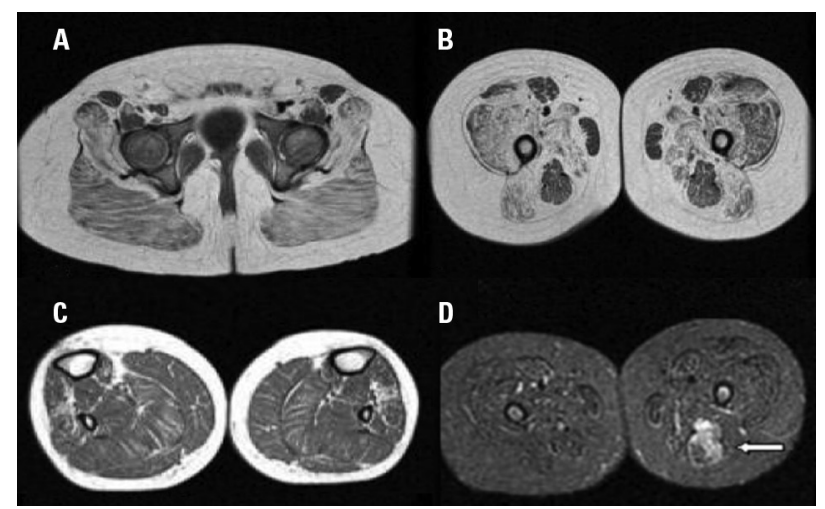

Fig 2. Muscular MNR. With images in the axial plan, sequences of T1 Fast Spin Echo (FSE) [A and C] and Short Tau Inversion Recovery (STIR) [D]. Diffuse muscular atrophy of the lower limbs is observed with compromise of the pelvis $[\mathrm{A}]$ and proximal extremities [B] more accentuated than in distal extremities [C]. STIR sequence in the proximal level shows hypersignal representing edema in the left semitendinosus muscle [arrow in D].

defined. In any way, HTLV-1 infection is a risk factor for muscle diseases.

ACKNOWLEDGMENT - The authors thank the pathologist doctor Cleto de Souza Dantas Walnut for his contribution.

\section{REFERENCES}

1. Morgan OS, Rodgers-Jonhson P, Mora C, Char G. HTLV-I and polymyositis in Jamaica. Lancet 1989;2:1184-1187.

2. Ribas JG, Melo GC. Mielopatia associada ao vírus linfotrópico humano de células T do tipo 1 (HTLV-1). Rev Soc Bras Med Trop 2002;35:377-384. 
3. Pinheiro SR, Lana-Peixoto MA, Proietti $A B$, Oréfice $F$, Lima-Martins MV, Proietti FA. HTLV-I associated uveitis, myelopathy, rheumatoid arthritis and Sjögren's syndrome. Arq Neuropsiquiatr 1995;53:777-781.

4. Gabbai AA, Wiley CA, Oliveira AS, et al. Skeletal muscle involvement in tropical spastic paraparesis/HTLV-1-associated myelopathy. Muscle Nerve 1994; 17:923-930.

5. Khan RB, Bertorini TE, Levin MC. HTLV-1 and its neurological complications. Neurologist 2001;7:271-278.

6. Dalakas MC. Inflammatory, immune, and viral aspects of inclusion-body myositis. Neurology 2006;66:33-38

7. Littleton ET, Man WD, Holton JL, et al. Human T cell leukaemia virus type I associated neuromuscular disease causing respiratory failure. J Neurol Neurosurg Psychiatry 2002;72:650-652.

8. Douen AG, Pringle CE, Guberman A. Human T-cell lymphotropic virus type
1 myositis, peripheral neuropathy, and cerebral white matter lesions in the absence of spastic paraparesis. Arch Neurol 1997;54:896-900.

9. Steven L, Franklin AM, Betul G, Mary LO, Ostrowzki. MRI in myopathy. Neurol Clin 2004:22:509-538.

10. Leon-Monzon M, IIla I, Dalakas MC. Polymyositis in patients infected with human T-cell leukemia virus type I: the role of the virus in the cause of the disease. Ann Neurol 1994;36:643-649.

11. Choy EHS, Hoogendijk JE, Lecky B, Winer JB. Immunosuppressant and immunomodulatory treatment for dermatomyositis and polymyositis. Available at http://www.cochrane.org/reviews/en/ab003643.html. Accessed November 15, 2006.

12. Castro-Costa CM, Araújo AQ, Menna-Barreto M, Penalva-de-Oliveira AC. Guia de manejo clínico do paciente com HTLV: aspectos neurológicos. Arq Neuropsiquiatr 2005;63:548-551. 